\title{
THE TOTAL AND AVAILABLE CONCENTRATIONS OF ESSENTIAT TRACE ELEMENTS IN AGRICULTURAL SOILS OF EASTERN CROATIA
}

Krunoslav KARALIĆ ${ }^{1 *}$, Zdenko LONČARIĆ ${ }^{1}$, Vladimir IVEZIĆ ${ }^{1}$, Brigita POPOVIĆ $^{1}$, Meri ENGLER ${ }^{1}$, Darko KEROVEC ${ }^{1}$, Vladimir ZEBEC ${ }^{1}$

\begin{abstract}
The research objective was to determine the influence of basic soil chemical properties on total concentration and available fractions of essential trace elements in the soil. Agrochemical soil analysis were conducted at two localities of different soil properties Berak and Vinogradci in eastern Croatia. The soil at the site Berak was eutric cambisol of neutral reaction ( $\mathrm{pH}$ average $\left(\mathrm{H}_{2} \mathrm{O}\right) 7.20$ ), while the soil in Vinogradci was luvisol of slightly acid reaction (average $\mathrm{pH}\left(\mathrm{H}_{2} \mathrm{O}\right)$ 5.87). Both soils were poor in organic matter and well supplied with phosphorus and potassium. As expected, at both analyzed sites the highest average concentrations were determined for total $\mathrm{Fe}, \mathrm{Mn}$ and $\mathrm{Zn}$ followed, and the lowest concentrations were for total $\mathrm{Cu}$. Higher total concentrations of analyzed microelements were recorded at the Berak site. The total concentrations of $\mathrm{Zn}$ and $\mathrm{Cu}$ in all analyzed soil samples were below the maximum permissible concentrations. The highest average concentration of available microelements fraction by EDTA Extraction, were at the Berak site determined for $\mathrm{Mn}(50.52 \mathrm{mg} / \mathrm{kg})$, then Fe $(21.77 \mathrm{mg} / \mathrm{kg}), \mathrm{Cu}$ $(4.78 \mathrm{mg} / \mathrm{kg})$, and the lowest for $\mathrm{Zn}(1.47 \mathrm{mg} / \mathrm{kg})$. At the Vinogradci site average concentrations of available fraction of microelements determined by EDTA extraction were the highest for $\mathrm{Fe}(77.09 \mathrm{mg} / \mathrm{kg})$, then $\mathrm{Mn}(30.75 \mathrm{mg} / \mathrm{kg}), \mathrm{Cu}(4.36 \mathrm{mg} / \mathrm{kg})$, and the lowest for $\mathrm{Zn}(1.76 \mathrm{mg} / \mathrm{kg})$. Identical order of average concentrations at both sites was also recorded for extraction with DTPA solution. Comparing available fraction of microelements by localities, higher average concentrations of $\mathrm{Mn}$ and $\mathrm{Cu}$ were found at the site Berak, while on site Vinogradci higher average concentrations were of $\mathrm{Fe}$ and $\mathrm{Zn}$. At both sites the DTPA method extracted more of Fe and Mn, an average of 51.06\% and $6.39 \%$ more than the EDTA method, but the method EDTA extracted more $\mathrm{Zn}$ and $\mathrm{Cu}$, an average of $127.10 \%$ and $100.40 \%$ than DTPA method. The smallest share of the available fraction of the total concentration was recorded for Fe $(0.06 \%$ by EDTA -

\footnotetext{
${ }^{1}$ University of Josip Juraj Strossmayer in Osijek, Faculty of Agriculture in Osijek, Kralja Petra Svačića 1d, Croatia

*Corresponding author: kkaralic@pfos.hr
} 
$0.09 \%$ by DTPA ), followed by Zn (1.20\% by DTPA $-2.74 \%$ by EDTA) and Mn (5.93\% by EDTA $-6.31 \%$ by DTPA), while the largest share was observed for $\mathrm{Cu}(10.92 \%$ by DTPA and $21.84 \%$ by EDTA).

Keywords: microelements, total concentrations, available fractions

\section{INTRODUCTION}

Soil reaction affects the soil chemical properties in wide range, especially soil nutrients mobility and plant availability. Furthermore, soil acidity and elemental toxicities or deficiencies associated with it, affects crops growth and restricts yields through the world (Rengel et al., 2003). The increase in cultivation intensity with the increasing demand for higher yields with better quality has resulted in increasing demand for microelements.

Microelements such as $\mathrm{Fe}, \mathrm{Mn} \mathrm{Zn}$ and $\mathrm{Cu}$ play an essential role in the assimilation and dissimilation processes of plants in terms of activators and inhibitors of metabolic processes. Availability of micronutrients in agricultural soils is defined with $\mathrm{pH}$ as main factor. Changes of soil reaction impacts to the $\mathrm{Fe}, \mathrm{Mn}, \mathrm{Zn}$ and $\mathrm{Cu}$ soil status turnover. Increase of fertilization may cause some negative effects because of changes in micronutrient availability (Györi, 2006). Zn and Fe deficiency are currently listed as major risk factors for human health globally (Cakmak, 2008). Micronutrient deficiency in general can noticeably reduce the performance and profitablity of agroecosystem (Fisher, 2008).

Soil extraction techniques to measure the status of available micronutrients for plants are important in the diagnosis of deficiency or toxicity (Garcia at all, 1997). Threfore, the aim of this paper was to was to determine the influence of basic soil chemical properties on total concentration (aqua regia) and available fractions (EDTA and DTPA) of essential trace elements ( $\mathrm{Fe}, \mathrm{Mn}, \mathrm{Zn} \mathrm{Cu}$ ) on acid and neutral soils of continental part of Croatia.

\section{MATERIAL AND METHODS}

Soil samples for conducted research were collected from arable soils $(0-30 \mathrm{~cm}$ depth) on location Vinogradci, from luvisol soil in type Osijek-baranja county and location Berak, eutric cambisol soil in Vukovar-srijem county. Both locations are situated in eastern part of continental Croatia. A total of 106 soil samples of arable soils were taken on both localities for agrochemical analysis. The basic methods of soil analysis included determination of soil $\mathrm{pH}$ in a suspension of soil and water as well as soil and $\mathrm{KCl}$ solution, humus content, content of available forms of phosphorus and potassium, hydrolytic acidity and $\mathrm{CaCO}_{3}$ content.

The total concentration of mineral elements in the soil, including the analyzed microelements are determined by various methods of partial or complete digestion of 
the soil (hydrofluoric acid, nitric acid, aqua regia). Soil samples for this investigation were digested in aqua regia according to method ISO, 1995b using freshly prepared mixture of $1 / 3 \mathrm{HNO}_{3}+2 / 3 \mathrm{HCl}$.

For determination of plant available $\mathrm{Fe}, \mathrm{Mn}, \mathrm{Zn}$ and $\mathrm{Cu}$ concentrations in soil the different extraction solutions (EDTA, DTPA, AA-EDTA, $\mathrm{HCl}$ and water) are used, and for this study extraction methods with a solution of EDTA (ethylenediaminetetraacetic acid) and DTPA solution (dietientiaminpentaoctena acid) were used. The extraction method with EDTA (Trierweiler and Lindsay, 1969) is commonly used in the Republic of Croatia.

\section{RESULTS AND DISCUSSION}

Basic agrochemical soil properties as soil $\mathrm{pH}$, humus content, plant available phosphorus and potassium and carbonate content were analyzed in all soil samples (Table 1). The soils at the site Berak were in average neutral $\left(\mathrm{pH}\right.$ average $\left.\left(\mathrm{H}_{2} \mathrm{O}\right) 7.20\right)$, moderately supplied with organic matter and well supplied with phosphorus and potassium, moderately calcareous and according to hydrolytic acidity liming was not required. The soils in Vinogradci were in average moderately acid (average $\mathrm{pH}\left(\mathrm{H}_{2} \mathrm{O}\right)$ 5.87), poor in organic matter and also poorly supplied with phosphorus and potassium, moderately calcareous and liming was not obligate but it could be beneficial.

Table 1. Basic soil properties

\begin{tabular}{|c|c|c|c|c|c|}
\hline & $\mathrm{pH}_{\mathrm{H}_{2} \mathrm{O}}$ & рНксl & $\begin{array}{l}\mathrm{AL}-\mathrm{P}_{2} \mathrm{O}_{5} \\
\mathrm{mg} / 100 \mathrm{~g} \\
\end{array}$ & $\begin{array}{c}\mathrm{AL}-\mathrm{K}_{2} \mathrm{O} \\
\mathrm{mg} / 100 \mathrm{~g} \\
\end{array}$ & $\begin{array}{c}\text { humus } \\
(\%)\end{array}$ \\
\hline Berak & $7.20 \mathrm{a}$ & $6.38 \mathrm{a}$ & $20.99 a$ & $24.31 \mathrm{a}$ & $2.08 \mathrm{a}$ \\
\hline Vinogradci & $5.87 \mathrm{~b}$ & $4.95 b$ & $14.09 \mathrm{a}$ & $17.79 \mathrm{~b}$ & $1.66 \mathrm{~b}$ \\
\hline Mean & 6.51 & 5.64 & 17.41 & 20.92 & 1.86 \\
\hline St. dev. & 1.13 & 1.22 & 20.47 & 6.67 & 0.36 \\
\hline
\end{tabular}

As expected, at both analyzed sites the highest average concentrations of total concetrations of essential trace elements were determined for total $\mathrm{Fe}, \mathrm{Mn}$ and $\mathrm{Zn}$ followed, and the lowest concentrations were for total $\mathrm{Cu}$ (Table 2).

Table 2. Total concentrations of microelements in soil ( $\mathrm{mg} / \mathrm{kg})$

\begin{tabular}{lcccc}
\hline & Fe & Mn & Zn & Cu \\
\hline \hline Berak & $30.134 \mathrm{a}$ & $839.5 \mathrm{a}$ & $62.82 \mathrm{a}$ & $21.75 \mathrm{a}$ \\
\hline Vinogradci & $26.469 \mathrm{~b}$ & $659.9 \mathrm{~b}$ & $53.92 \mathrm{~b}$ & $15.94 \mathrm{~b}$ \\
\hline Mean & 28.233 & 746.3 & 58.21 & 18.73 \\
\hline St. dev. & 3.051 & 163.3 & 7.59 & 3.78 \\
\hline
\end{tabular}


Higher total concentrations of all analyzed microelements were recorded at the Berak site compared to Vinogradci site. It is important to point out that total concentrations of $\mathrm{Zn}$ and $\mathrm{Cu}$ in all analyzed soil samples (Berak and Vinogradci) were below the maximum permissible concentrations, which are for $\mathrm{Zn} 150.00 \mathrm{mg} / \mathrm{kg}$ and for $\mathrm{Cu} 90 \mathrm{mg} / \mathrm{kg}$.

The highest average concentration of available microelements fraction by EDTA extraction (Table 3) were at the Berak site determined for Mn $(50.52 \mathrm{mg} / \mathrm{kg})$, then Fe $(21.77 \mathrm{mg} / \mathrm{kg}), \mathrm{Cu}(4.78 \mathrm{mg} / \mathrm{kg})$, and the lowest for $\mathrm{Zn}(1.47 \mathrm{mg} / \mathrm{kg})$. At the Vinogradci site average concentrations of available fraction of microelements determined by EDTA extraction were the highest for $\mathrm{Fe}(104.62 \mathrm{mg} / \mathrm{kg})$, then $\mathrm{Mn}(38.60 \mathrm{mg} / \mathrm{kg}), \mathrm{Cu}(3.46$ $\mathrm{mg} / \mathrm{kg})$, and the lowest for $\mathrm{Zn}(1.69 \mathrm{mg} / \mathrm{kg})$.

Table 3. Available concentrations of microelements in soil by EDTA extraction

\begin{tabular}{lcccc}
\hline & Fe & Mn & Zn & Cu \\
\hline \hline Berak & $21.77 \mathrm{~b}$ & $50.52 \mathrm{a}$ & $1.47 \mathrm{a}$ & $4.78 \mathrm{a}$ \\
\hline Vinogradci & $104.62 \mathrm{a}$ & $38.60 \mathrm{~b}$ & $1.69 \mathrm{a}$ & $3.46 \mathrm{~b}$ \\
\hline Mean & 64.76 & 46.95 & 1.58 & 4.10 \\
\hline St.dev. & 67.42 & 21.40 & 0.94 & 1.10 \\
\hline
\end{tabular}

Identical order of average available concentrations at Berak site $(\mathrm{Mn}>\mathrm{Fe}>\mathrm{Cu}>\mathrm{Zn})$ and at Vinogradci site $(\mathrm{Fe}>\mathrm{Mn}>\mathrm{Cu}>\mathrm{Zn}$ ) was recorded for extraction with DTPA solution (Table 4).

Table 4. Available concentrations of microelements in soil by DTPA extraction

\begin{tabular}{lcccc}
\hline & Fe & Mn & Zn & Cu \\
\hline \hline Berak & $43.44 \mathrm{~b}$ & $51.13 \mathrm{a}$ & $0.68 \mathrm{a}$ & $2.28 \mathrm{a}$ \\
\hline Vinogradci & $107.31 \mathrm{a}$ & $43.07 \mathrm{~b}$ & $0.71 \mathrm{a}$ & $1.81 \mathrm{~b}$ \\
\hline Mean & 76.58 & 44.40 & 0.69 & 2.03 \\
\hline St.dev. & 53.11 & 21.15 & 0.44 & 0.51 \\
\hline
\end{tabular}

Analysed neutral and acid soils significantly differed in soil $\mathrm{pH}$, soil organic matter content and plant available potassium. Average total concentrations of microelements for all soils significantly differed in decreasing order Fe (28233 $\mathrm{mg} / \mathrm{kg})>\mathrm{Mn}(746.3)>\mathrm{Zn}(58.21 \mathrm{mg} / \mathrm{kg})>\mathrm{Cu}(18.73 \mathrm{mg} / \mathrm{kg})$ according to all samples mean. Significant difference between neutral (Berak) and acid soils (Vinogradci) in total concentrations of microelements was recorded for all analysed essential trace elements where significantly higher total concentrations were observed in neutral soils (Berak site). 
Comparing available fractions of microelements by localities, plant available fractions of $\mathrm{Fe}$ and $\mathrm{Zn}$ extracted with EDTA or DTPA were significantly higher in acid soils (Vinogradci site), while on neutral soils (Berak site) significantly higher average concentrations in the same extractants were observed for $\mathrm{Mn}$ and $\mathrm{Cu}$ (Table 5). At both sites the DTPA method extracted more of Fe and Mn, an average of $51.06 \%$ and $6.39 \%$ more than the EDTA method, but the method EDTA extracted more $\mathrm{Zn}$ and $\mathrm{Cu}$, an average of $127.10 \%$ and $100.40 \%$ than DTPA method.

Table 5. Total and available microelements content in neutral and acid soils

\begin{tabular}{|c|c|c|c|c|c|c|c|c|c|c|}
\hline & \multicolumn{5}{|c|}{ Neutral soils (Berak) } & \multicolumn{5}{|c|}{ Acid soils (Vinogradei) } \\
\hline & $\begin{array}{r}\text { Total } \\
\mathrm{mg} / \mathrm{kg}\end{array}$ & $\begin{array}{l}\text { EDTA } \\
\mathrm{mg} / \mathrm{kg}\end{array}$ & $\begin{array}{l}\text { EDTA } \\
\% \text { of } \mathrm{T}\end{array}$ & $\begin{array}{l}\text { DTPA } \\
\mathrm{mg} / \mathrm{kg}\end{array}$ & $\begin{array}{l}\text { DTPA } \\
\% \text { of T }\end{array}$ & $\begin{array}{c}\text { Total } \\
\mathrm{mg} / \mathrm{kg}\end{array}$ & $\begin{array}{l}\text { EDTA } \\
\mathrm{mg} / \mathrm{kg}\end{array}$ & $\begin{array}{l}\text { EDTA } \\
\% \text { of T }\end{array}$ & $\begin{array}{l}\text { DTPA } \\
\mathrm{mg} / \mathrm{kg}\end{array}$ & $\begin{array}{l}\text { DTPA } \\
\% \text { of T }\end{array}$ \\
\hline $\mathrm{Fe}$ & 30134 & 21.77 & 0.07 & 43.44 & 0.14 & 26469 & 104.62 & 0.39 & 107.31 & 0.40 \\
\hline Mn & 839.5 & 50.52 & 6.02 & 51.13 & 6.09 & 659.9 & 38.60 & 5.85 & 43.07 & 6.53 \\
\hline $\mathbf{Z n}$ & 62.82 & 1.47 & 2.34 & 0.68 & 1.08 & 53.92 & 1.69 & 3.13 & 0.71 & 1.32 \\
\hline $\mathrm{Cu}$ & 21.75 & 4.78 & 21.98 & 2.28 & 10.48 & 15.94 & 3.46 & 21.71 & 1.81 & 11.35 \\
\hline
\end{tabular}

In all analysed soils and in both extraction solutions the lowest share of available fraction in total content were determined for Fe, follows $\mathrm{Zn}$, then $\mathrm{Mn}$ and $\mathrm{Cu}$ had the highest share of the available fraction in total content. According to all samples mean, share of the available fraction of the total concentration was for Fe $0.06 \%$ by EDTA and $0.09 \%$ by DTPA extraction, for Zn $2.74 \%$ by EDTA and $1.20 \%$ by DTPA solution, for Mn $5.93 \%$ by EDTA and $6.31 \%$ by DTPA extraction, and for $\mathrm{Cu} 21.84 \%$ by EDTA and $10.92 \%$ by DTPA method.

Although acid soils had lower total concentrations of all analyzed microelements compared to neutral soils, the share of available fractions of the total concentrations were higher in acid soils than in neutral soils for all analyzed microelements.

Significant correlations between total concentrations of microelements and amounts extracted by EDTA or DTPA were not observed. On the other hand, very significant correlations were determined for plant available $\mathrm{Fe}, \mathrm{Mn}, \mathrm{Zn}$ and $\mathrm{Cu}$ between EDTA and DTPA (Table 6). 
Table 6. Correlation coefficients between EDTA and DTPA solution for analysed microelements

\begin{tabular}{lccc}
\hline & all soils & neutral soils & acid soils \\
\hline \hline Fe & 0,832 & 0,877 & 0,741 \\
$\mathbf{M n}$ & 0,848 & 0,808 & 0,919 \\
$\mathbf{Z n}$ & 0,957 & 0,855 & 0,974 \\
\hline $\mathbf{C u}$ & 0,748 & 0,351 & 0,829 \\
\hline
\end{tabular}

Three extracted microelements by EDTA and by DTPA extraction solution were the most comparable in acid soils ( $\mathrm{Mn} \mathrm{r}=0,92, \mathrm{Zn} \mathrm{r}=0,97, \mathrm{Cu} \mathrm{r}=0,83 ; \mathrm{n}=55$ ). The highest correlation among EDTA and DTPA method for Fe was obtained in neutral soils $(\mathrm{r}=0,88 ; \mathrm{n}=51)$. There was no significant correlation between EDTA and DTPA extracted $\mathrm{Cu}$ in neutral soils.

\section{CONCLUSIONS}

It can be concluded that EDTA solution extracted higher plant available concentrations of $\mathrm{Zn}$ and $\mathrm{Cu}$ than DTPA solution regardless of soil $\mathrm{pH}$. Lončaric et al. (2008) reported for soils in Croatia that the ratio of available and total concentrations of micronutrients was strongly impacted by soil $\mathrm{pH}$ and all analysed elements had higher plant available concentrations in acid soils compared to calcareous soils. At the same time, DTPA solution resulted with higher concentrations of plant available Fe and Mn compared to EDTA method. Higher portion of available fractions of the total concentrations were observed in acid soils than in neutral soils for analyzed microelements. The highest ratio of available fraction of total content was recorded for $\mathrm{Cu}$ and the lowest for $\mathrm{Fe}$ in neutral and acid soils. Very significant correlations were determined between EDTA and DTPA method, and available $\mathrm{Mn}, \mathrm{Zn}$ and $\mathrm{Cu}$ showed the highest correlation in acid soils, while Fe showed the highest correlations in neutral soils.

\section{REFERENCES}

Cakmak, I. 2008. Enrichment of cereal grains with zinc: Agronomic or genetic biofortification? Plant and Soil 302:1-17.

Egner, H., Riehm, H., Domingo, W.R. 1960. Untersuchungen über die chemische Bodenanalyse als Grundlage für die Beurteilung des Nahrstoffzustandes der Boden II. Chemische Extractionsmetoden zu Phosphor- und Kaliumbestimmung. K. Lantbr. Hogsk. Annlr. W.R. 26, 199-215. 
Fisher, G.E.J. 2008. Micronutrients and animal nutrition and the link between the application ofmicronutrients to crops and animal health. Turkish Journal of Agriculture and Forestry 32: 221-233.

Garcia, A., Deiorio, A.F., Barros, M., Bargiela, M., Rendina, A. 1997. Comparison of soil tests to determine micronutrients status in Argentina soils. Communications in soil science and plant analysis, 28: 19-20. 1777-1792.

Györi, Z. 2006. Effect of mineral fertilization on the $\mathrm{Mn}, \mathrm{Zn}, \mathrm{Cu}$ and $\mathrm{Sr}$ content of winter wheat. Cereal Research Communications, 34: 1. 461-646.

International Standard Organisation. 1994. Soil quality - Determination of pH. ISO 10390: 1994(E).

International Standard Organisation. 1995. Soil quality - Extraction of trace elements soluble in aqua regia. ISO 11466: 1995(E).

International Standard Organisation. 1998. Soil quality - Determination of organic carbon by sulfochromic oxidation. ISO 14235: 1998(E).

Jones, J.B. 2001. Laboratory guide for conducting soil tests and plant analysis. CRC Press LLC. Boca Raton. Florida. USA.

Lončarić, Z., Karalić, K., Popović, B., Rastija, D., Vukobratović, M. 2008. Total and plant available micronutrients in acidic and calcareous soils in Croatia. Cereal Research Communications. 36 (1) (S5): 331-334.

Rengel, Z. 2003. Role of plant cation/anion uptake ratio in soil acidification. In: Rengel Z (ed) handbook of soil acidity. Marcel Dekker, Inc., New York/Basel, pp 57-81.

Trierweiler, F.J., Lindsay, W,L. 1969. EDTA-ammonium carbonate soil test for Zn. ProcSoil Sci Soc Am. 33: 49-54. 